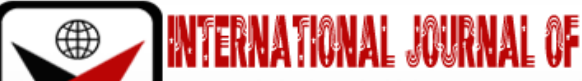

ISSN 2278-0211 (Online)

\section{The Impact of Leverage on Environmental Disclosure of Quoted Firms in Nigeria}

\author{
Nurudeen Mohammed Moshud \\ Lecturer, Abdu Gusau Polytechnic, TalataMafara, Zamfara State,Nigeria \\ Oladele Jamiu Olanrewaju \\ Lecturer, Umaru Ali Shinkafi Polytechnic, Sokoto, Sokoto State, Nigeria \\ Abu Isaac Friday \\ Manager, Zenith Bank, Sokoto, Sokoto State, Nigeria
}

\begin{abstract}
:
This study has focused on assessing the impact of leverage on environmental disclosure of quoted firms in Nigeria, for the year 2016. The study has been undertaken on all companies quoted on the Nigeria Stock Exchange (NSE). This study examines the impact of leverage on Environmental Disclosures of quoted firms in Nigeria. The study adopts a cross-sectional research design. The study used a sample of 82 firms from the total population of 176 firms listed on the Nigeria Stock Exchange for a period of 5 years ranging from 2012 to 2016. Method of data collection was secondary data. The study employed Binary regression Logistic techniques as the method of data analysis. The findings of the study indicate that a non -significant relationship exist between leverage and environmental disclosures with a probability value which shows 0.0977 at $5 \%$ level of significance. Since the P-value calculated of 0.0977 is greater than 5\% level of significance, the study therefore accepts the null hypotheses that no relationship exists between profitability of quoted firms and environmental disclosures. The study therefore concludes that firm voluntarily discloses the effect of their operations on the environment they operate. The study recommends that government should compel companies aspiring to be listed on the Nigeria Stock Exchange to provide environmental risks disclosures as one of the pre-requisites for listing and should be enforced to continually provide such environmental disclosures while presenting their annual reports and accounts.
\end{abstract}

Keywords: Leverage, environmental, disclosure

\section{Introduction}

Over the years, the responsibility and duties of organizations was an economic performance right from inception, in order to ensure continuation of the activities of the organization requires a commitment to maximize profits for shareholder groups (Balabanis, 1998). However, focusing only on financial performance without any considerations to environmental impacts becomes a source of global concern to many stakeholder groups especially with the increasing cases of corporate collapse over non-financial issues disclosure during the last decades (Ql-Oquili\&Kouhy, 2006). Corporate response to these global concerns led to the emergence of the concept of Environmental Disclosure as a western phenomenon in the business literature (Macarulla\&Talalweh, 2012).

Environmental Disclosure or Reporting for not only their financial actions, but also the non-financial implications of their activities has become a challenge for many countries, especially in the developed world (Macarulla\&Talalweh, 2012). Particularly, Environmental Disclosure practices in these countries such as Europe, USA and Canada gained increasing importance in the literature of accounting, as numerous western studies confirmed that the profit standard is no longer the only approach used to evaluate corporate performance (Bhattacharyya 2015).

Meanwhile, the non-financial activities are considered as important as financial activities (Amato 2009). In essence, the two are considered positively related as Thomas \& Hunger (2008) specifically argue that corporate business activities should be run in a socially acceptable way if they desire to improve their image, and establish credibility for their actions with their various stakeholders. Because building a good relationship with the stakeholders in the long run can ensure sustainability of a business (Uddin, 2008), thus, business sustainability would be helpful to create value for all stakeholders (Woodward, 1996).

Similarly, it is documented by several western studies including for example those conducted by Griffin \& Mahon (1997), Roman (1999), and Rowley and Berman (2000) that, Environmental disclosure strategy is an important means to contributing to global sustainability. And this is the reason why Environmental Disclosure initiatives currently have gained so much importance in those countries (Uddin 2008).

Many studies examine the influence of financial leverage on voluntary corporate social disclosure. The results of their studies are either inconclusive or contradictory, reporting positive or sometimes negative results. Sembiring (2005); 
Rahman and Widyasari (2008); Putra (2009); Veronica (2009); Untari (2010); Yulita (2010) discovered that financial leverage has no effect on corporate social responsibility disclosure. Apriwenni (2009); Purnasiwi (2011); Kolsi, (2012); Hajji\&Ghazali (2013) discovered in their studies that financial leverage affects corporate social responsibility disclosure.

\subsection{Statement of the Research Problem}

It is possible that Environmental disclosure impacts on financial performance of a firm in the long run. The Environmental reporting is voluntary in Nigeria but companies are engaging in it to enhance reputation, increase their brand visibility, and show their commitment for concern on community, environmental protection or employee welfare. Environmental disclosure is becoming popular unlike in the past when companies included a general statement about community involvement in their annual reports. Studies conducted on effect of environmental disclosure on financial performance yielded either a negative, neutral or positive association thus indicating inconsistent results. In addition, many studies have focused on developed markets as opposed to emerging markets. Although some firms have committed to investments in Corporate Sustainability Programs through the allocation of more resources, other companies have resisted. This could, at least in part, be because of the debate on whether a corporation should go beyond maximizing the profit of its owners as the only social responsibility of business, to being accountable for any of its actions to the environment and society. The question of what really motivates environmental disclosure initiatives and reporting becomes principal. The integration of environmental programs in the operational strategies of companies is a new reporting practice in Nigeria but there has been increased adoption among the listed firms. However, the value of the practice is still unknown. Previous studies have focused on the effect of firms' characteristics and level of environmental disclosure but this study employs a different approach of, considering themes of environmental disclosure and their effect on financial performance. This study therefore seeks to determine the impact of Leverage on Environmental Disclosure of listed companies on the Nigeria Stock Exchange.

\subsection{Research Objective}

To determine the relationship between the leverage of a company and environmental disclosure.

\subsection{Research Hypothesis}

The study is to be guided by the following research hypotheses:

- $\mathrm{Ho}_{1}$ : No relationship exists between the leverage of a company and environmental disclosure.

\section{Literature Review}

Toluwa, Okun\&Ikhenade (2015). The objective of this study is to investigate the Determinants of Environmental Disclosure in Nigeria. The specific objectives therefore, are to examine the effect of industry type, leverage and firm size on environmental disclosure on a sample size of 50 companies from both manufacturing and non-manufacturing sectors. The statistical method employed was the Binary logistic panel data regression. The study revealed that industry type, firm size has positive relationship, while leverage has no significant effect on environmental disclosure.

Ndukwe\& John (2015) using a sample companies drawn from oil and gas sectors of the Nigerian stock exchange for 2008-2013 financial years, found that there is no significant relationship between profit and corporate environmental disclosures. He therefore concludes that voluntary stance of environmental reporting has often be used as a cliche for companies to under report their effects on the environment and this is responsible for the negligence of several corporate entities with regards to corporate social and environmental reporting.

Ikpor\& Agha (2016) examine the determinants of voluntary disclosure quality among listed firms on Nigeria Stock Exchange. The study focusses on how profitability, leverage, size and board composition affect the quality of corporate social disclosure. The study used Ex-post facto research design and judgmental sampling technique to determine sample population. The study excluded some firms based on the fact that some firms' usage of financial leverage substantially differs from the other. The study fails to recognize that debt to equity ratio can be applied generally to all the firms. This could have help to increase the sample population of the study. The study found leverage to be significant and negatively related to the disclosure quality of listed firms in Nigeria. Ikpor\& Agha (2016), investigates the extent to which company characteristics influence voluntary disclosure practices among Kenyan companies. The study discovered that leverage positively and significantly affect voluntary disclosure. Review of empirical studies shows that most of the studies were based on using different firm attributes impact on environmental disclosures, there was no study with special and particular narrowing down on the impact of Leverage on environmental disclosure, hence the gap this research intends to cover.

Modugbu\&Eboigbe (2017) investigate the relationship between firm size, leverage and corporate social disclosure level. The study adopted the longitudinal research design. The result of their study shows a significant negative relationship between leverage and mandatory disclosure.

Elshabasy (2017) examined the impact of corporate characteristics on environmental information disclosure among listed firms in Egypt. The study discovered that there is an insignificant relationship between Firm Financial Leverage on environmental information disclosure.

Soyinka (2017) examined the relationship between firm size, leverage and return on asset on corporate social responsibility disclosure. The study used data from audited annual reports and accounts of the listed Deposit Money Banks in Nigeria. The study discovered leverage was found to exhibit a negative relationship with corporate social responsibility. The above studies discovered negative relationship between leverage and corporate social disclosure level, environmental information disclosure and corporate social responsibility disclosure. 
Egbunike\&Tarilaye, (2017) examined the association between firm's specific attributes (firm size, earnings, leverage and governance) and voluntary environmental disclosure with evidence from listed manufacturing companies in Nigeria. The study discovered that there is a positive relationship between environmental disclosure and leverage of the studied manufacturing companies in Nigeria. The study focuses only on environmental disclosure and ignores both economic and social disclosure.

Sarumpaet (2005) using a sample size of 252 listed companies in Indonesia, investigated the relationship between financial performance and environmental reporting. It concluded that that financial performance had no significant relationship with environmental performance.

Brammer\&Pavelin (2006) states that there are differences between sectors in terms of determinants which affect disclosure decisions and there is a positive relationship between the size of the firms and the quality of environmental information. Decision makers in firms, particularly in developed countries, play significant roles in voluntary environmental disclosure. Investors do not obtain some information if decision-makers believe that investors do not need to have information or this information is available in other sources (Cormier \&Magnan, 2003). Managerial decisions in companies with regard to environmental disclosure are subject to determinants. Some researchers noted in their studies that the size of the company is one of the determinants of managerial decisions, and indicates a positive relationship between firm size and the level of environmental disclosure.

$\mathrm{Lu}$ (2008) suggests firms increased the level of environmental disclosure, because of the surge of environmentalism. The researchers indicated disclosure correlated with increases in social concern about environments and relationships between firm's environmental performances with kinds of industry.

Plumlee, Brown \& Marshall (2009) concluded that, the financial situation of the company influences the decision of environmental disclosure. This study found that when the company's financial situation is well, the company will be more likely to provide environmental information.

\subsection{Environmental Disclosure in Nigeria}

Nigeria, being one of the world largest producers of crude oil to some extent, has experienced some rapid economic and technological development that has, in turn brought about higher levels of education, better standards of living and greater affluence amongst Nigerians. This better economic position has also meant higher levels of education amongst its people. Consequently, of late, there appears to be increased public concern and awareness for corporate social environmental impact. This could also be due to the prominent role played by the non-governmental organizations (NGOs), such as the Green Alliance Nigeria, and the Federal Environmental Protection Agency (FEPA) of Nigeria, in lobbying for the preservation and conservation of the environment. The intense media scrutiny and coverage of environmental problems - including cases of open continuous gas flaring, environmental degradation in the Niger-Delta regions, burning, indiscriminate land and hill clearing, and toxic waste dumping- have also contributed to public concern for the detrimental effects of business operations on our natural environment. Due to this change in public concern and awareness on environmental issues, it may be the case then that companies in Nigeria must respond to such changes by providing environmental disclosures within the annual reports.

\section{Methodology}

The study employed the cross-sectional research design and the justification for the suitability of the research design is based on the fact that several firms were observed over a period of five years (2012-2016). For the purpose of this research, data was gathered mainly through secondary sources of data collection given the fact that the study is correlation in nature and is basically attempting to establish relationship of the variables. The data was for a period of 5 years ranging from 2012-2016 and was extracted from the annual reports of the firms, NSE fact book and daily official lists of the NSE. The justification for selecting the time period above was based on the availability of data and the need to conduct a more current and up to date study.

Binary logistic regression method was employed as the data analysis method. Binary regressions have the objective of obtaining a functional relationship between a transformed qualitative variable called Logit or Probit and the predictor variables which can either be quantitative or qualitative. The choice of binary regression models (Probit, or Logit regression) to relate the explanatory variables to the probability of a firm's willingness to report environmental information was based on the limited nature of the dependent variable and the inability of the Ordinary Least Square (OLS) multiple regression model to yield reliable coefficients and inference statistics in situation where the dependent variable is binary ( 0 and 1 ). The binary regression models unlike others are based on the use of dichotomous dependent variable, in which an observation scores one (1) if it is present and zero (0) if it is otherwise. The study adopts the two widely used binary regression models (Logit and Probit). The differentiating factor between these models is based on the type of probability distribution they assume. Logistic binary regression follows a cumulative logistic probability distribution while the binary probit assumes cumulative normal distribution. Both methods were used to analyse the data, but the binary probit was chosen over the logit after conducting goodness for fitness test, and it was found to have a higher percentage of fitness, therefore the probit model was adopted.

\subsection{Model Specification}

The model for the study is specified thus;

ENVD $=\mathrm{F}$ (LEV)

This can be re-specified in regression form as

$\mathrm{ENVD}=\mathrm{B} 0+\beta 1 \mathrm{LEV}+\mathrm{Ut}$ 
Where: ENVD = Environmental Disclosure

LEV = leverage

\section{Results and Discussions}

- $\mathrm{H}_{01}$ :No relationship exists between the leverage of companies and environmental disclosure.

The dependent variable is Environmental Disclosure, while Leverage (LEV) is the independent variable. The summary of the regression is presented in Table 1 below.

\begin{tabular}{|c|c|c|c|c|}
\hline Variable & Coefficient & Std Err & Z- Stat & P-values \\
\hline Lev & 1.830472 & 1.105158 & 1.656299 & 0.0977 \\
\hline \multicolumn{6}{c}{ Table 1: Summary of Leverage } \\
Source:E-Views 9 output 2021
\end{tabular}

Table 1 reveals that the coefficient has a positive value of 1.830472, which was not significant at $5 \%$ level of significance, though was significant at $10 \%$ level of significance. This is to say that the leverage of this firm which is borrowings of firms has no significant but a positive relationship with environmental disclosure.

The probability value shows 0.0977 at $5 \%$ level of significance. Since the P. value calculated of 0.0977 is greater than $5 \%$ level of significance, the study therefore, accept the null hypotheses that there is no relationship between leverage and environmental disclosure.

This non-significance of the relationship above as revealed by the study is in line with the findings of Ahmed \&Nicolls (1994): Mohamed \&Tamoi (2006) and Toluwa, Okun\&Ikhenade (2015) which found no statistical relationship between leverage and environmental disclosure. According to Healy \&Palepu (1995), Leverage may be determinants of environmental disclosure as firms may need to resolve certain information asymmetric and agency issues with the stakeholders.

\section{Conclusion and Recommendation}

The study, after data collected and eventually subjected to statistical analysis using the binary probit regressions model has examined the determinants of environmental disclosure in annual reports by quoted firms in Nigeria. The findings therefore of the study gives a true picture of the determinants of environmental disclosures in the annual reports of quoted firms in Nigeria of a sample of eighty- two (82) firms quoted on the Nigeria Stock Exchange emanating from the use of availability sampling on the total population of 176 quoted firms. The hypotheses of the study were formulated to empirically test if there is any significant relationship between leverage and environmental disclosures.

From the study and findings above, it was found that different determinants exist that makes or motivate firms to disclose information relating to how companies' operations affect the environments in which they are located.

Also, there is a no significance relationship between environmental disclosures in the annual reports of quoted firms in Nigeria and their leverage. The result also shows that leverage has a p-value of 0.0977 which was not significant at $5 \%$ but was found to be significant at $10 \%$. The stated hypothesis is therefore accepted based on the statistical p-value that is greater than 5\%. This finding of this study is also in line with that ofToluwa, Okun\&Ikhenade (2015).

The implication of this finding is that companies with relatively lower financial leverage will have sufficient funds for financing environmental disclosure and report its activities to its stakeholders. Environmental disclosure will help the management to reduce pressure from creditors. However, highly leverage companies are more likely to comply with Environmental responsibility regulations. This may encourage them to report their environmental activities to their stakeholders.

Environmental disclosure is a set company's commitments to ensure that it operate in an environment that is economically, environmentally and socially sustainable whilst ensuring that a balance is maintained in respect of diverse stakeholders' interests. Environmental disclosure represents a policy undertaking by organization to ensure that the effect of the company's operations on the environment in which it operates is communicated to different stakeholders in their annual reports. This has attracted so much attention over the last few decades with the continual agitation of the effect of company's operations on the environments where they are located and specific example is the Niger-Delta situation. Owners of businesses through their representative i.e., managers need to compare the cost associated with disclosing environmental information and the benefits expected to accrue also to the organization. The study was conducted in order to provide an insight into the impact of leverage on environmental disclosures of quoted firms in Nigeria.

\section{References}

i. Ahmad, NSM. (2004). Corporate Environmental Disclosure in Libya: Evidence and environmental determinism theory. United Kingdom: PhD thesis, Napier University, Edinburgh.

ii. Ahmed, K., and Nicholls, D. (1994). the Impact of Non-financial Company Characteristics on Mandatory Compliance in Developing Countries: The Case of Bangladesh. the International Journal of Accounting, 29(1), 60-77.

iii. Al-Gamrh, BAA. (2010). Social and Environmental Disclosure in Saudi Companies. Universiti Utara Malaysia.

iv. Bhattcharyya, A. (2015). Factors Aassociated with Social and Environmental Reporting of Australian Companies. Australian Accounting, Business and Finance Journal, 25-50.

v. Brammer, S., \&Pavelin, S. (2006). Factors influencing the quality of corporate environmental disclosure. Business Strategy and the Environment, 17(2), 120-136. 
vi. Eljayash, K. M.; James, K. \& Kong, E. (2012). The Quantity and Quality of Environmental Disclosure in Annual Reports of National Oil and Gas Companies in Middle East and North America. International Journal of Economics and Finance, 4 (10).

vii. Eljayash, K. M.; James, K. \& Kong, E. (2013). Environmental Disclosure practices in National Oil and Gas Corporations and international oil and gas corporations operating in organization of Arab petroleum exporting countries. Int.J.Bus, Econ.Law. 2, 35-52.

viii. Healy, P.M.; Palepu, K.G. (2001). Information asymmetry, corporate disclosure, and the capital markets: A review of the empirical disclosure literature. Journal of Accounting and Economics, 31(1), 405-440.

ix. Lu, Y. (2008). A study of environmental disclosures made by Chinese mineral extraction corporations.

X. Mohammed, Z. \&Tamoi, J. (2006). Corporate Social Disclosure of Construction Companies in Malaysia. Malaysian Accounting Review, 5(1),, 85-114.

xi. Ndukwe,O.D \& John C.O. (2014). Determinant of environmental disclosures in Nigeria: A case study of oil and gas companies. International Accounting Journal 4(3), 145-152.

xii. Neu, D., Warsame, H., \&Pedwell, K. (1998). Managing public impressions: environmental disclosures in annual reports. Accounting, Organizations and Society, 23(3), 265-282.

xiii. Nyirenda, G., Ngwakwe, C. and Ambe, C., n.d. (n.d.). Environmental Management Practices and Firm Performance in a South African Mining Firm. Managing Global Transitions 11(3), 243-260.

xiv. Oba, V.C and Fodio, M.I. (2012). Comparative Analysis of Environmental Disclosure in oil and Gas and Construction Industries in Nigeria. Journal of Sustainable Development in Africa 14(6).

xv. O'Donovan, G. (1997). Legitimacy theory and corporate environmental disclosure: Some case study evidence. AAANZ Annual Conference. Hobart, Tasmania.

xvi. Patelli L, Prencipe A. (2007). The relationship between voluntary disclosure and independent directors in the presence of a dominant shareholder. Eur Account Rev 16(1):, 5-33.

xvii. Patten, D. M. (1992). Intra-industry environmental disclosures in response to the Alaskan oil spill: a note on legitimacy theory. Accounting, Organizations and Society 17(5), 471-475.

xviii. Patten, D. M. (1991). Exposure, legitimacy, and social disclosure. Journal of Accounting and Public Policy, 10(4), 297-308.

xix. Patten, D. M. (2002). The relation between environmental performance and environmental disclosure: a research note. Accounting, Organizations and Society 27(8), 763-773.

xx. Plumlee, M, Brown, D \& Marshall, RS. (2009). Voluntary environmental disclosure quality and firm value: roles of venue and industry type. University of Utah and Portland State University.

xxi. Pramanik, A, Shil, N \& Das, B. (2009). Corporate Environmental Reporting: An Emerging Issue in the Corporate World. International Journal of Business and Management, 3(12), 146.

xxii. Purnomo, P.K. \&Widianingsih, L.P. (2012). The Influence of Environmental Performance on Financial Performance with Corporate Social Responsibility. Review of Intergrative Business \& Economics Research, 1 (1), 57-69.

xxiii. Rahahleh, Y. (2011). Means for Implementation of Environmental Accounting Jordanian Perspectives. International Journal of Business and Management,6( 3), 124.

xxiv. Roberts, C. B. (1991). Environmental disclosures: a note on reporting practices in mainland Europe. Accounting, Auditing \& Accountability Journal, 4(3), 62-71.

xxv. Roberts, R. W. (1992). Determinants of corporate social responsibility disclosure: an application of stakeholder theory. Accounting. Organizations and Society, 17(6),, 595-612.

xxvi. Rouf A. (2011). The corporate social responsibility disclosure: A study of listed companies in Bangladesh. Bus Econ Res J 2(3), 19-32.

xxvii. Sahay, A. (2004). Environmental reporting by Indian corporations. Corporate Social Responsibility and Environmental Management, vol. 11, no. 1, 12-22.

xxviii. Salama, A.,. (2005). A Note on the Impact of Environmental Performance on Financial Performance. Structural Change and Dynamics, 16 (3),, 413-421.

xxix. Sarumpaet S. (2005). The Relationship between Financial Performance and Environmental of Indonesian Companies. Journal Akuntansi\&keuangan,7( 2),, 89-98.

xxx. Savage, A. (1994). Corporate social disclosure practices in South Africa: A research note. Social and Environmental Accounting,14( 1), 2-4.

xxxi. Schneider, T. E. (2010). Is environmental performance a determinant of bond pricing? Evidence from the U.S. pulp and paper and chemical industries. Working Paper SSRN.

xxxii. Secci, D. (2005). The Italian experience in social reporting: an empirical analysis. . Corporate Social Responsibility and Environmental Management, 13, , 135-149.

xxxiii. Shane, P. B., \& Spicer, B. H. (1983). Market response to environmental information produced outside the firm. The Accounting Review, 58(3),, 521-538.

xxxiv. Sharfman, M. \& Fernando, C. (2008). Environmental Risk Management and the Cost of Capital. Strategic Management Journal 29, 569-592.

xxxv. Silva Monteiro, S. M., \&Aibar-Guzmán, B. (2010). Determinants of environmental disclosure in the annual reports of large companies operating in Portugal. Corporate Social Responsibility and Environmental Management, 17(4), 185-204. 
xxxvi. Singh, D. \& Ahuja, J. (1983). Corporate social reporting in India. International Journal of Accounting, 18(2), 151-169.

xxxvii. Smith, M,. (2003). 'Environmental disclosure and performance reporting in Malaysia. Asian Review of Accounting, 15(2), 185-199.

xxxviii. Smith, M, Yahya, K \&Amiruddin, A. (2007). Environmental disclosure and performance reporting in Malaysia. Asian Review of Accounting, 15(2), 185-199.

xxxix. Suttipun, Muttanachai - Stanton, Patricia. (2012). Determinants of environmental disclosure in Thai corporate annual report. International Journal of Accounting and Financial Reporting,2( 1), 99-115.

xl. Toluwa, O.,Okun, O.0 \&Ikhenade, A.F. (2015). Determinants environmental disclosure in Nigeria. International Journal of Advanced Academic Research (Social \& Management Sciences).

xli. Toms, J. S. (2002). Firm resources, quality signals and the determinants of corporate environmental reputation: some UK evidence. British Accounting Review 34(3), 257-282.

xlii. Trotman, K. T., \& Bradley, G. W. (n.d.). Associations between social responsibility disclosure and characteristics of companies. Accounting, Organizations and Society, 6(4),, 355.

xliii. Tsang, Eric W. K. (1998). A longitudinal study of corporate social reporting in Singapore The case of the banking, food and beverages and hotel industries. Accounting Auditing and Accountability Journal, 11( 5), 624635.

xliv. Ullmann, A. A. (1985). Data in search of a theory: a critical examination of the relationships among social performance, social disclosure, and economic performance of U. S. firms. The Academy of Management Review, $10(3), 540-557$.

xlv. Uwuigbe U \&Egbide B. (2012). Corporate social responsibility disclosures in Nigeria: A study of listed financial and non-financial firms. J Manag Sustain 2(1):, 160-169.

xlvi. Wagner, M., N. V. Phu, T. Azomahou and W. Wehrmeyer. (2002). The relationship between the environmental and economic performance of firms: an empirical analysis of the European paper industry. Corporate Social Responsibility and Environmental Management 9(3), 133.

xlvii. Weir C \& Laing D. (2001). Governance structure, director independence and corporate performance in the UK. Eur Bus Rev 13(2), 86-94.

xlviii. Wilmshurst, T.D \& Frost, G.R. (2000). Corporate environmental reporting. . Accounting, Auditing \& Accountability Journal.

xlix. Wise, V \& Ali M. (2009). Corporate governance and corporate social responsibility in Bangladesh with special reference to commercial banks.

l. Wiseman, J. (1982). An evaluation of environmental disclosures made in corporate annual reports. Accounting, Organizations \& Society, 7(1), 53-63.

li. Wong, L. T., \&Fryxell, G. E. (2004). Stakeholder influences on environmental management practices: a study of fleet operations in Hong Kong (SAR), China. Transportation Journal, 43(4), 22-35.

lii. World Business Council for Sustainable Development. WBCSD. (2002). Sustainable development reporting: striking the balance.

liii. Xie B, Davidson, WN \&Dalt PJ. (2001). Earnings management and Corporate Governance: The roles of the board and the audit committee.

liv. Ying, Y. (2006). 'Environmental Disclosure in Hong Kong, with Comparison to United Kingdom and Canada. Hong Kong : Hong Kong Baptist University.

lv. Yusoff, H \& Lehman, G. (2006). 'International differences on corporate environmental disclosure practices: A comparison between Malaysia and Australia' in 4th International Conference on Accounting and Finance in Transition. South Australia.: University of South Australia.

lvi. Zeng, S. X., Hu, X. D., Yin, H. T., \& Tam, C. M. (2012). Factors that drive Chinese listed companies in voluntary disclosure of environmental information. Journal of Business Ethics, 109(3), 309-321. 